Ssciendo Studia Anglica Posnaniensia 54s1 (2019): 287-314

doi: 10.2478/stap-2019-0014

\title{
TRACING PATTERNS OF INTRA-SPEAKER VARIATION IN EARLY ENGLISH CORRESPONDENCE: A CHANGE FROM ABOVE IN THE PASTON LETTERS
}

\author{
JUAN M. HERNÁNDEZ-CAMPOY, J. CAMILO CONDE-SILVESTRE \\ AND TAMARA GARCÍA-VIDAL ${ }^{1}$
}

\begin{abstract}
The aim of this paper is to explore the impact of social and context factors on the diffusion of a linguistic change from above, namely the deployment of the spelling innovation $<$ th $>$ in fifteenthcentury English, and especially in some letters from the well-known Paston collection of correspondence. We particularly focus on the socio-stylistic route of this change from above, observing the sociolinguistic behaviour of some letter writers (members of the Paston family) in connection with the social-professional status of their recipients, the interpersonal relationship with them, as well as the contexts and styles of the letters. In this way, different dimensions of this change from above in progress in fifteenth-century English can be reconstructed.
\end{abstract}

Keywords: Historical sociolinguistics; sociolinguistic styles; change from above; history of English spelling; late Middle English; Paston Letters.

\section{Theoretical background}

After three decades of continuous research, historical sociolinguistics is now a well-established discipline with a methodology that has allowed researchers to trace new dimensions of historically attested changes along the social and linguistic dimensions, as well as to test some widely-accepted sociolinguistic tenets or 'universals': the curvilinear hypothesis, overt-covert prestige patterns,

* $\quad$ Financial support for this research has been crucially provided by the DGICT of the Spanish Ministerio de Economía y Competitividad (FFI2014-56084-P) and by Fundación Séneca, the Murcian Agency for Science and Technology (19331-PHCS-14 and 20585-EE-18).

1 University of Murcia, Departamento de Filología Inglesa, Facultad de Letras, Campus de La Merced,30071 Murcia, Spain,jmcampoy@um.es, jcconde@um.es, tamara.garcia4@um.es. 
life-span-change, generational change, age-grading, social networks or changes from above and changes from below, among others. ${ }^{2}$ A number of these studies are based on historical 'ego' documents - diaries, travel accounts, witness depositions in court records and, especially, letters, both private and official which have become instrumental sources in shedding light on language variation and change in the past. ${ }^{3}$

Correspondence, in this context, is particularly relevant. Unlike many surviving documents from the past - especially from the earliest stages - letters are non-anonymous texts, signed by an author and addressed to one known reader (or more than one); the identification of both participants in the act of communication implies that psycho-biographical data about them can, with a certain amount of luck, be reconstructed. The prospect of retrieving personal information facilitates the analysis of some of the sociolinguistic variables traditionally correlated with linguistic production - age, gender, education, professional background, social status, social network, mobility, etc. - and permits the tracing of the diffusion of historically attested changes over the social, geographical, and temporal spaces, only if the surviving letters are autographed documents and their written words were the proper 'utterance' of their authors, with no mediation of scribes or secretaries (Nevala \& Palander-Collin 2005; Nevalainen 2007; Palander-Collin 2010). Moreover, as a text type, some characteristics of letters from the past - linguistic features expressing personal involvement, interaction or personal stance, among others (Biber 1995: 283-300, 2001: 98-99; Biber \& Finegan 1997) - are shared with spoken registers, so that correspondence becomes the written genre more likely to approach the vernacular (Nevalainen 2007: 13). This is vital for historical sociolinguistics, which aims at reconstructing those linguistic processess (variation and change) that are often bred in this medium. Finally, letters reflect the personal communicative style of an author, who maintains and negotiates a particular social relationship with his/her addressees in a given situation and with a certain purpose, and often as part of a local community of practice: whether the relationship is closer - based on kinship, friendship, etc. - or more distant, professional or business-like. Correspondence, therefore, has been understood as better suited than other genres for research on the variety of styles that could have affected changes in the history

2 For reviews of current research in the field within English studies see, among others, Nevalainen (2006, 2011, 2015), Nevalainen \& Raumolin-Brunberg (2012), Auer et al. (2015) and Conde-Silvestre (2016a). See also the textbooks and handbooks by Nevalainen \& Raumolin-Brunberg (1996, 2017), Conde-Silvestre (2007), Hernández-Campoy \& CondeSilvestre (2012), and Millar (2012).

3 For a comprehensive list, see the Corpus Research Database provided by the Research Unit for Variation, Contacts and Change in English (VARIENG) at the University of Helsinki: https://www.helsinki.fi/varieng/CoRD/index.html. [Accesed on March 22, 2019)]. 
of languages. As a matter of fact, typologically, letters may contain as many styles of writing as the relationship between their participants permits (Romaine 1998: 18; Palander-Collin, Nevala \& Nurmi 2009: 17-20; Auer 2015).

\section{Objectives: Language change and stylistic variation}

Linguistic change interacts in complex ways with patterns of stylistic variation, as the diaphasic range of a given language is one of the most sensitive sociolinguistic symptoms of social change and differentiation (Ure 1982: 7). Style, therefore, as John Rickford and Penelope Eckert have highlighted, enjoys a pivotal position in the correlation of social and linguistic variation (2001: 1). However, it is well known that all change involves variability, but not all instances of variability involve change. The observation of stylistic variability, as William Labov (1966a) pioneeringly showed, is crucial to detect and understand phenomena such as linguistic change in progress: "[s]tyle-shifting is not found in the earliest stages of linguistic change, but becomes stronger as the change matures and is maximized if the feature is assigned prestige or social stigma as the change reaches completion" (Labov 2001: 86).

In this paper, a socio-stylistic analysis of letters from the past is accomplished with the aim of exploring the diffusion of one Middle English change in progress - the substitution of the spelling $\langle\mathrm{p}>$ with $<$ th $>$ - in connection with some sociolinguistic principles: the impact of audience-design and self-monitoring based patterns of style-shifting and socio-stylistic differentiation on this change from above. ${ }^{4}$ For this purpose, the Uniformitarian Principle is a necessary tenet. Originally conceived by Neogrammarian linguists in the nineteenth century (Christy 1983), it was reformulated by Labov (1972) to describe the idea that the linguistic and extralinguistic constraints that affect present-day speech communities must not be totally different from those operating in the past. This implies that languages probably varied in the same patterned ways in the past as they have been observed to do today, and that the development of linguistic systems always occurs in relation to the sociohistorical situation of speakers (Labov 1972: 275, 1994: 21-25). Accordingly, the sociolinguistic behaviour of, for example, late fifteenth- century speakers may have been determined, to some

4 This piece of research is related to two long-term projects carried out at the University of Murcia (Spain), "Sociolinguistic models of stylistic variation in English historical correspondence" (HiStylVar) and "Communities of practice and stylistic variation in English historical correspondence", whose results and conclusions are chiefly published in CondeSilvestre (2016b, 2019) and Hernández-Campoy \& García-Vidal (2018a, 2018b). The aim of the projects is to explore the motivations and mechanisms for stylistic variation in English historical correspondence corpora and in connection with some of the present-day theoretical models developed for its study. 
extent, by similar factors to those currently operating - attitudinal and sociodemographic issues, mobility and the everyday contacts between individuals, the purpose of speech production, and the role and status of addressees, among others - which means that the conclusions obtained by sociolinguists on patterns of socio-stylistic variation in the present can be extended back in time, in this case to late Middle and Early Modern English communities. Likewise, in addition to tracing language change and variation, sociolinguistic behaviours found by studying historical corpora of correspondence also permit the reconstruction of early community values as reflected in the local communicative competence developed for language choice in style-shifting processes, as well as the detection of how social meanings are transmitted in interactional communication. ${ }^{5}$

Our contribution will thus particularly focus on changes from above and their social diffusion. In the classical formulation put forward by Labov (1972: 122-142, 1994: 74-80), linguistic changes could operate "from above" or "from below the level of social awareness", i.e., consciously or unconsciously. Although, as Miriam Meyerhoff (2006: 171) points out, 'above' does not necessarily indicate that a linguistic change originates in higher status social groups and 'below' in lower social ones, it is also true that changes from above often function in connection with explicit social conditions, of which speakers are aware, since they are based on the received socio-economic and professional structures prevalent in a given community. Moreover, they tend to match the formal end of the stylistic continuum, often deriving from an external norm which becomes socially accepted. In modern Western societies, these changes are usually led by speakers from the central groups in the social hierarchies, particularly the lower middle classes, who hypercorrect their production of a given variant in the careful and more conscious styles. This often implies a stylistic shift along the informal-formal continuum, either because speakers self-monitor their speech, producing more careful utterances, or in response to pressures from the audience. Changes from above have been widely attested in the present and the past of several languages, and they can be acknowledged as a kind of sociolinguistic universal - see, among others, Labov (1966a: 206-208), Trudgill (1974: 95), Reid (1978), Romaine (1978, 1982), Mattheier (1981), Maas (1988), Voitl (1988), Hickey (1999), Mihmet et al. (2000). In this paper, the observation of the sociolinguistic behaviour of letter writers in connection to the social status of their recipients -the different socio-professional ranks and the interpersonal relations between addresser and addressee - may provide us with information on the socio-stylistic route followed by some linguistic innovations, as attested cases of changes from above.

See studies by Elspa $\beta$ (2002), Tieken-Boon van Ostade (2005, 2006), Sairio (2009), Alexandropoulos (2015), Auer (2015), Schiegg (2016), Hernández-Campoy \& García-Vidal (2018a, 2018b), or Voeste (2018), for example. 


\section{Methodology}

\subsection{Archival source}

Data used for the present study are based on epistolary documents drawn from the electronic edition of the Paston Letters (first part), currently available online from the Corpus of Middle English Prose and Verse at the University of Michigan (https:/quod.lib.umich.edu/c/cme/paston [accessed on April 20, 2019]) and the University of Oxford Text Archive (https://ota.oucs.ox.ac.uk/headers/1685.xml/ [accessed on April 20, 2019]), and which largely correspond to the printed one published by Norman Davis (1971-1976). The Paston Letters is the name given to a collection of 422 authored documents (letters and notes) written by fifteen members from different generations of this Norfolk family, mainly between 1425 and 1503 , with roughly 246,353 words. The preservation of collections of late fifteenth-century private correspondence which, like this one, involve writers of different sex, age, social extraction, personal circumstances, and geographical location, offers a very useful corpus to carry out quantitative sociolinguistic analysis. The fact that they were written by members of the family and addressed to other members partly accounts for their preservation (Davis 1971-1976: xv) ${ }^{6}$

The historical and philological interest of these documents is outstanding, not only because they offer data on the political and domestic history of the fifteenth century - especially in the context of the English War of the Roses (1455-1487) - but also because they were composed at a crucial period in the development of the English language, when a range of fundamental linguistic changes were in progress. $^{7}$ In this sense, ever since Richard Blume undertook his analysis of the

6 The possibility of establishing a one-to-one relationship between the linguistic output of each letter and the personal profile of its producer is crucial for historical sociolinguistic research and involves the following dimensions, which should be carefully considered when planning research in the field: (a) authorship of the original, i.e., whether the text was actually written by the person in whose name it was composed or by a secretary; (b) the prospects of identifying as many details as possible of the writer's social background at large; and (c) editorial intrusion in the original with respect to mainly grammar and spelling (Nevalainen \& Raumolin-Brunberg 1996: 43; see also Schneider 2002). As regards the Paston Letters, Norman Davis, editor of the collections, carefully notes whether the documents he transcribes are autographs, drafts, or dictated and copied by a scribe (1971-1976: xxxvi-xxxix). As regards editorial intervention, Davis also ackowledges that some abbreviations are expanded and certain curls and flourishes eliminated. These practices do not impinge on the general distribution of the two spellings analysed here, $<\mathrm{th}>$ and $\langle\mathrm{p}>$, except for some occassional uses of the variant $\langle\mathrm{y}\rangle$ instead of $\langle\mathrm{p}\rangle$ in the definite article $y^{e}$ which the editor replaces in order to avoid confusion with the plural personal pronoun ye (lxxxiii; see also fn. 8 below).

7 Further information on the Paston family and their historical context can be found in Davis (1971-1976), Bennett (1995 [1932]), Richmond (1996, 2000, 2002, 2004), Barber (1986), Gies \& Gies (1998), and Castor (2004), among others. 
language of the Paston Letters in 1882, the corpus has been subject to a number of studies from different linguistic perspectives - see, among others, Davis (1989 [1954]), González Escribano (1982, 1985), Schäfer (1996), Gómez-Soliño (1997), Tanabe (1999), and Wood (2007). Some authors have adopted a historical sociolinguistic approach. For instance, Norman Davis (1983) compared some idiolectal traits peculiar to the brothers John Paston II and John Paston III, from the third generation of the family; Alexander Bergs (2005) has analysed the deployment of some morphosyntactic features in connection with external variables and, especially, with the social networks established by some of the correspondents; finally, Juan M. Hernández-Campoy and J. Camilo CondeSilvestre (1999) have studied the adoption of incipient standard spelling norms by different members of the family, also in connection with such factors as gender, age and social and/or geographical mobility - see also Conde-Silvestre \& Hernández-Campoy (2004, 2013), Hernández-Campoy (2008, 2016b), and Hernández-Campoy \& Conde-Silvestre (2015). These sociolinguistic approaches confirm the relevance of the Paston Letters as a corpus, with documents from three generations of family members, whose analysis may help to delve into some of the linguistic changes that took place in the period.

\subsection{Informants: The Paston family}

The Pastons were not nobility but nouveau riche landowners. In fact, the initial social position of this Norfolk family was not originally as high as it became later in the century. As such, the founder of the family, Clement Paston, is described in a document from the 1450s as "a good plain husbandman [who] lived on the land that he had in Paston, on which he kept a plough at all times of the year" (Barber 1986: 11). The family fortunes improved with William Paston I (13781444) who, after having been trained as a lawyer in the Inns of Court in London, acted as counsel for the city of Norwich from 1412, and in 1415 became steward to the Duke of Norfolk, beginning a successful career that brought him a good local reputation. He married Agnes Berry in 1420 and became Justice of the Common Bench in 1429. After his death in 1444, the family became involved in lawsuits, intrigues, and even violent conflicts about land and legal rights. In this context of turmoil, John Paston I (1421-1466) - one of the informants for this study - also throve in society. He was educated at Trinity Hall and Peterhouse, Cambridge, and the Inner Temple in London. As the eldest son of William and Agnes Paston, he took over the family estates and wealth. As far as his career is concerned, he became Justice of Peace in Norfolk (1447, 1456-1457 and 1460 1466), Knight of the Shire (1455), and Member of Parliament for Norfolk (1460 1462). His letters range from 1444 to 1465, when he was a middle-aged man (2344 years old). Later members of the family, like John Paston II (1442-1479) and 
John Paston III (1444-1504) - John I's sons - were to join the Court nobility and moved further up the social scale, when, after performing several diplomatic and military services to the Crown, at home and abroad, they were knighted in 1463 and 1487, respectively. This is a clear clue to the upward social mobility of a family that certainly prospered in the course of three generations, to the point of being described by Helen Castor as "an ambitious nouveau riche family striving to leave their humble origins behind as the Wars of the Roses unfold around them" (2004: 73). In this context, the social career of John Paston III - another relevant informant for this study - is also outstanding. He often travelled throughout the country (Wales, Newcastle) and abroad in the service of the Duke of Norfolk and in diplomatic errands, for instance accompanying princess Margaret to Bruges on the occasion of her marriage to the Duke of Burgundy in 1468. He also participated in the battle of Barnet (1471), where he was wounded. In the 1470s and 1480s, he remained in the manors that the family owned in Norfolk, although he also visited London and Calais: as MP for Norwich (14851486), Sheriff of Norfolk and Suffolk, or councillor to Lord High Admiral, the Earl of Oxford. In 1487, after his participation at the battle of Stoke, he was knighted and in the 1490s performed several duties as deputy of the Earl. His letters range from 1461 to 1485 , between the ages of seventeen and forty-one.

The position of John Paston I and his son, John Paston III, is remarkable, not only because they were clearly involved in a process of upward social mobility, but also because they were core members of the family. The social networks of the individual family members, as reconstructed by Bergs (2005: 69-70) on the evidence of the letters written and received, show that John Paston I and John Paston III occupy a central position, together with Margaret Paston (see Figures 1 and 2). Their central location in the family network can be a clue to characterise their linguistic behaviour as typical of the "innovators", following the definition by James and Lesley Milroy: central, influential network members who start to use the innovations while establishing strong ties with other speakers within their own close-knit network, while being at the same time weakly tied to innovators from outside through their ample contacts with speakers of different origins and extraction and their attested geographical mobility (1985: 364-370; see also, L. Milroy 1987, 2002: 562-563 and Conde-Silvestre 2012: 334). The linguistic analysis carried out by Bergs (2005: 261) confirms this hypothesis. The correlation between each member of the family's network and some morphosyntactic features in their letters - personal pronouns, relative connectors and constructions with a 'light' verb of the type V+NP - situate John I and John III in the middle of a continuum extending from the most advanced speakers (the "early adopters") - William Paston II and John Paston II respectively for the second and third generation of the family - to the most conservative - probably like "lames" in the Labovian sense (1973): Margaret Paston and Margery Paston. 


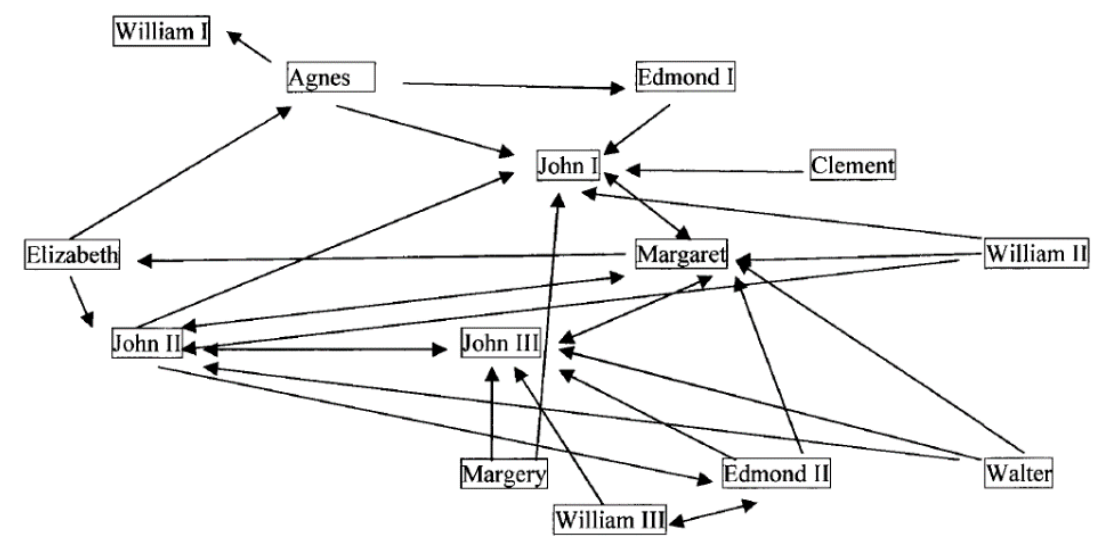

Figure 1. The Pastons network(s): Internal links (Bergs 2005: 69)

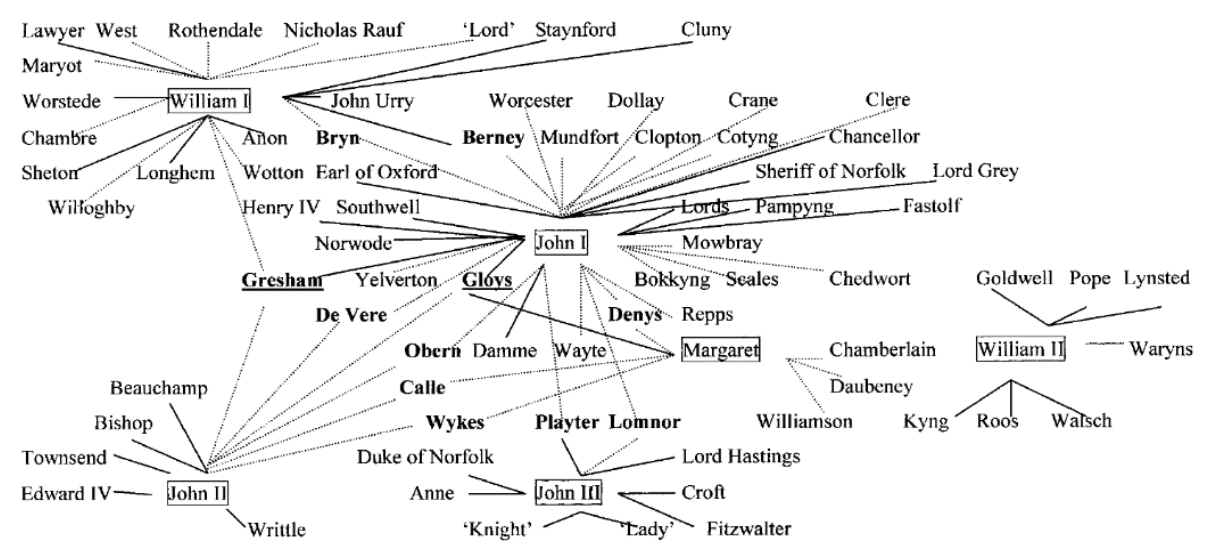

Figure 2. The Pastons network(s): External links (Bergs 2005: 70)

\subsection{Linguistic variable: (th)}

In this study, we focus on an innovative practice of late Middle English orthography: the progressive adoption of the Latin-based spelling variant $<$ th $>$, a prestigious continental practice, at the expense of the old runic $\langle p\rangle$. This linguistic change exhibits the characteristics of a change from above, as described before. It is well-known that the spellings $\langle\mathrm{p}\rangle$ and $\langle\partial\rangle-$ despite some graphotactic conditioning in early texts, with $<\mathrm{p}>$ used initially and $<\gamma>$ medially (Stenroos 2006: 12) - were indistinctively used in OE for the voiced and voiceless dental fricative consonants $[\theta]$ and $[\delta]$ and began to be replaced in ME by $<$ th $>$, 
taken from the Latin alphabet. The progress of this change also involves the disappearance of $<\boldsymbol{\gamma}>$ which, according to Roger Lass "began to yield to $<\mathrm{p}>$ in the thirteenth century, though it remains sporadically through the fourteenth" (1992: 36). ${ }^{8}$ Despite having been adopted later than $<\partial>$, the popularity and the longer survival of $<p>$ is explained by Donald Scragg "by the fact that confusion with similarly shaped graphs was less likely" (1974: 10; see also Hogg 1992: 76). The use of $<$ th $>$ was already attested in the Anglo-Saxon period, particularly in the spelling of vernacular names in Latin texts (Benskin 1982: 19), but it was reintroduced in the twelfth century, through Latin influence on Anglo-Norman scribes (Hogg 1992: 77; Lass 1992: 36; Benskin 1977: 506-507, 1982: 18; Stenroos 2006). It is worth quoting the explanation by Benskin in this respect:

\begin{abstract}
In the aftermath of the Norman Conquest, English as a written language was displaced for nearly all administrative purposes by Latin and, to a lesser extent, by French. Immigrant Norman scribes, given the frequent task of spelling in their Latin and French texts English vernacular names having [ $\theta]$, did merely what any number of English scribes from before the Conquest would have done: they wrote $<$ th $>$. For some of these continental writers, $<$ th $>$ may perhaps already have been a familiar combination: those who had read or written much Biblical texts would certainly have been aware of it. (Benskin 1982: 19; emphasis in the original)
\end{abstract}

As such, the Latin-based spelling became popular during the fourteenth century (Blake 1992: 10). Both Latin and Biblical influence point to the presence of external prestigious norms, which certainly triggered this spelling change, whose diffusion in writing is unquestionable. Thus, the spread of $<$ th $>$ can be classified as a historical change operating above the level of social awareness, in connection with social and stylistic factors, and diffusing along the social space in the careful and conscious styles, acquiring overt prestige and becoming part of the accepted linguistic norm: a typical change from above. Research carried out on the text types favouring the change confirms this idea. For instance, Merja Stenroos has studied the distribution of these spellings in the texts listed in the Linguistic Atlas of Late Mediaeval English; her approach not only validates the increasing rate of diffusion of the innovative $<$ th $>$ in the course of the fifteenth century - with $30 \%$ of occurrences in the first half and $50 \%$ in the second - but it also sanctions the preference for this spelling in official document texts of the period, where $<$ th $>$

8 The spelling variant $<\mathrm{y}>$ is also attested in the period. This was a modified version of $<\mathrm{p}>$ appearing in abbreviations like $y^{e}$ and $y^{t}$ instead of pe and pat respectively (Lass 1992: 36; see also Benskin 1982). The origin of these forms lies in the confusion of $\langle y\rangle$ and $\langle p\rangle$ in some scribal hands, which makes it hard to decide on their status as sociolinguistic variants. A different situation would have held in the north, where the merger shows a wider distribution and even some phonotactic constraints, "with $<\mathrm{y}>$ (and sometimes $<\mathrm{p}>$ ) to be

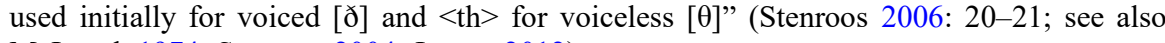
McIntosh 1974; Stenroos 2004; Jensen 2012). 
was virtually universal, while literary texts still retained a majority of $\langle\mathrm{p}>$ forms (Stenroos 2004: 277-278, 2006: 20-21). This observation is supported by Jensen's analysis of some scribal documents from Yorkshire, belonging, in this case, to documentary and religious (prose) text types (2012). The spelling $<$ th $>$ shows a clearer chronological progress in the former, but not in the latter, and, while it is dominant in lexical words in both, it is not as widespread in grammatical words in religious texts as it is in documentary ones. ${ }^{9}$ This would certainly mean that the innovation $<$ th $>$ was preferred (a) first in lexical and then in grammatical words and (b) in the most careful and self-conscious texts. As a change from above, $<$ th $>$ started to appear also in other learned contexts, such as the spelling of scientific and legal or administrative texts according to Rissanen (1999, 2000) and Taavitsainen (2000).

As regards procedure, all instances of $\langle$ th $>$ and $\langle p>$ in the letters by the male members of the Paston family were drawn by means of the concordance package Wordsmith 5.0 (https://www.lexically.net/), which facilitated the detection and quantification of the different possibilities for each spelling variant in each possible combination, even within the same document. The results were tabulated for each informant and also arranged on a letter-addressee basis.

\subsection{Audience and formality}

In order to study style-shifting in epistolary interactional communication and how the process influences language change, the sociolinguistic behaviour of informants (letter writers from the Paston family) has been observed on the basis of their addressees (audience) and context types (formality). As stated above, the fact that letters were not conceived or produced for publication provides a rich source of information on less-carefully monitored styles (see Biber \& Finegan 1989; Auer 2015). For the purpose of our study, we thus assume that speakers could probably have self-monitored their linguistic production more or less consciously, in connection with the informalityformality continuum or with the attention they paid to their writing practices; this probably involved their engagement in processes of style-shifting in response to their respective audience-membership, i.e., to the assigned roles of their interlocutors and the way they were actually or potentially addressed. Speakers - members of the Paston family in this case - would use a verbal repertoire with different styles within a continuum of formality and the choice

9 Our own analysis of texts from the period 1420-1500 in the Helsinki Corpus also supports this hypothesis. The percentage of $<$ th $>$ spellings in all text-types reaches $52 \%$ (with 10,691 occurrence out of 20,157 in raw terms), but the figure soars to $78 \%$ when the input is restricted to legal and official letters and documents $(2,981$ out of 3,685$)$. 
of one variant or another may have been conditioned by the attention paid to the documents they produced in connection with the intended audience - see Labov (1966a), Bell (1984), Coupland (2007: 54-81), and Hernández-Campoy (2016a: 95-130). In the case of a change from above, like the use of $<$ th $>$ for variable (th), it is our contention that the rate of the innovation would certainly have increased in the more formal styles and in the letters addressed to the recipients of the higher social status. Suzanne Romaine (1982) also found that formal styles were the locus for the introduction of prestige innovations. Similarly, Wolfgang Dressler and Ruth Wodak have observed that "one of the most important sources of diachronic change of a standard language is the spread of optional rules downwards from more formal styles until they become obligatory for all styles or the input is restructured" (1982: 350).

As regards the Paston correspondence, one of the studies mentioned above is especially relevant for our purposes here. In "The social diffusion of linguistic innovations in fifteenth century England: Chancery spellings in private correspondence" (Hernández-Campoy \& Conde-Silvestre 1999) we analysed progress in time and style of some fifteenth-century innovative spelling variants for variables (sh), (wh), and (u) in the letters written by some members of the Paston family: William Paston I, Clement Paston II (his son) and John Paston II (William's grandson). The variable 'time' was easily identified by tracing the date of the letters, the family relationship between the correspondents, and their age at the time of writing. The categorisation of 'style' and the formality or informality of each text was established on the basis of the relationship between addresser and addressee and on the subject matter: "the context of style is a speaker - a first person, an I, an ego, an identity or identities - together with the situation she or he is in" (Bell 2001: 139; emphasis in the original). In this way, letters exchanged between brothers or sent by a husband to his wife dealing with domestic matters and lawsuits were typically informal, while the official letters sent by William Paston I were considered samples of formal style (1999: 262-263). The comparison of the variants used in the formal texts written by some Pastons between 1425 and 1430 and those used in the informal documents of other family members in the 1470s shows a noticeable step in the diffusion of the incipient standard forms $<\mathrm{sh}>,<\mathrm{wh}>$, and $<\mathrm{u}>$ : the formal style in the 1420 s $(79 \%)$ was similar to the informal one used about fifty years later $(73 \%)$ in the 1470 s (see Figure 3). These results suggested that the implementation of the more standard-like innovations progressed from formal to informal styles over time. The increasing appearance of the new variants in informal texts implied a greater degree of proto-standardisation. Regarding each variable, the spelling $<\mathrm{wh}>$ for variable (wh) was completely adopted in the $1470 \mathrm{~s}$, when it reached $100 \%$ in the informal texts. The diffusion of $<\mathrm{sh}>$ and $<u>$ was, however, still in progress, going through some of the stages in the 
transition from the categorical use of the non-standard variants to its categorical replacement by the incipient standard ones. Variable (sh) in particular was to be in a stage of great variability, having very close frequencies of usage for both the proto-standard $(56 \%)$ and the non-standard $(44 \%)$ variants in the informal letters of the 1470s. However, the standard form $<\mathrm{u}>$ for variable $(\mathrm{u})$ was still in the initial stages of change, being wholly implemented in only $25 \%$ of cases in informal texts of the same decade.

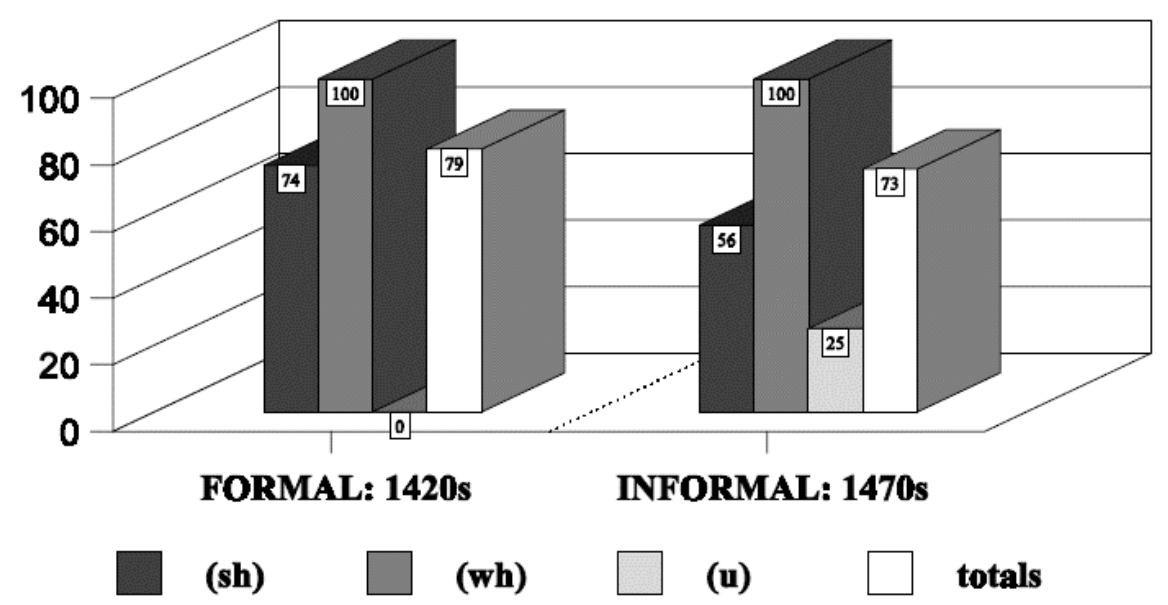

Figure 3. Percentages of incipient standard forms per styles in the Paston Letters (after Hernández-Campoy \& Conde-Silvestre 1999: 262; Figure 3)

With the aim of further exploring how this tenet works in the Paston Letters, contextual information touching on the stylistic range between formality and informality has been reconstructed in this paper by paying attention to the profiles of the addressees of the letters, in connection with different socio-professional ranks and with the type of interpersonal relations consistently found in other corpora of correspondence from the late Middle English period, as accomplished by Juan M. Hernández-Campoy and Tamara García-Vidal (2018b; see also Raumolin-Brunberg 1996: 26). The application of Allan Bell's models of Audience Design $(1984,2001)$ to intra-speaker variation in the Paston Letters has allowed them to find addressee-based patterns of style-shifting in the communicative interaction of late medieval individuals, in line with Bell's sociolinguistic characterisation of style in terms of both rules and roles. The strong salience of variable (th) in the process of an ongoing linguistic change from above in the fifteenth century, in a context of high sociolinguistic instability, makes it a perfect linguistic resource for style-shifting and facilitates interactional 
correlations at the sender-receiver level. Given that private written correspondence is intended as a dialogic exchange within the local community of practice, addressivity, relationality, and recipiency are key elements that reflect the personal accommodative competence of authors, their particular social relationships with addressees, and the situation and purpose of the letter: whether the relationship is closer (e.g., kinship, friendship, etc.) or more distant (professional, business-like, etc.). In the case of the Paston family, interaction typically occurs with people situated above them on the social scale, such as members of the royalty, the nobility, and the clergy: these contacts would probably entail more attention paid to the text and a more formal style. Interaction in the Paston letters can also be established with equals, like relatives and other members of the minor gentry; in this case, the writer would pay less attention to his production, which appears in a more informal style (see Table 1). Finally, a certain amount of interaction with professionals - especially in the field of law is also attested; in this case, although their social status is lower than the gentry rank attained by some of the Pastons, linguistically the technicality of their register and its relationship to incipient standard norms (see Rissanen 1999, 2000) may have conferred prestige on them, so that the interaction with lower-status speakers from this group may have facilitated the adoption of some incipient standard innovations by members of the gentry group, like the Pastons. This would also entail some attention to written production on the part of the Paston correspondents whose stylistic output would be more formal than the one characterising the letters addressed to relatives and family members.

Table 1. Typical social ranks and contexts of interaction in letters by members of the Paston family

\begin{tabular}{l|l|l}
\hline $\begin{array}{l}\text { Social } \\
\text { position }\end{array}$ & Addressee & \multicolumn{1}{c}{ Role } \\
\hline \multirow{3}{*}{ Higher } & Royalty & king, queen, prince, princess \\
\cline { 2 - 3 } & Nobility & duke, marquess, earl, viscount \\
\cline { 2 - 3 } & Clergy & archbishop, bishop \\
\hline \multirow{3}{*}{ Equal } & Minor gentry & knight, esquire, gentleman \\
\cline { 2 - 3 } & Relatives & brother, sister, mother, father, etc \\
\cline { 2 - 3 } & Partner & wife, husband \\
\hline \multirow{2}{*}{ Lower } & Professionals & $\begin{array}{l}\text { army officer, government official, lawyer, } \\
\text { medical doctor, etc. }\end{array}$ \\
\hline
\end{tabular}

Unlike Hernández-Campoy and García-Vidal (2018b), who exclusively focused on sent letters, in the present paper both sent letters and drafts are scrutinised jointly in order to observe the aggregate linguistic behaviour of the Pastons in terms of an 
individual's verbal repertoire and their possible patterned sociolinguistic practices. In this exploration of the progress of language change through intra-speaker variation as a reflection of its social evaluation and subsequent embedding, the study of the linguistic repertoire becomes relevant. The range of variation determines the individuals' verbal repertoire and their communicative competence to apply different registers and styles. According to the Principle of Range of Variability, the variation that any individual shows in their speech will never exceed that of social variation; i.e., it would never be greater than the differences between the social groups that their style-shifting is derived from (see Meyerhoff 2006: 44; Hernández-Campoy 2016a: 82-91) - unless hypercorrection occurs (see Labov 1966b). In the context of Bell's style axiom (1984), this means that intraspeaker variation is a function of inter-speaker variation, since the wider social variation is, the wider stylistic variation will be. Given that the same linguistic variables operate simultaneously on both social and stylistic dimensions, and given that social evaluation is the engine linking both, the range of variation exhibited in our Paston informants' communicative interaction with different socially-ranked addressees will act as a tangible measure of the progress of the linguistic change under investigation and its social esteem and vitality.

\section{Analysis and results}

In a previous article, "Tracing the generational progress of language change in fifteenth century English. The diffusion of $<$ th $>$ in the Paston Letters" (CondeSilvestre \& Hernández-Campoy 2013), the spread of this change in progress was traced in the Paston correspondence longitudinally. The tabulation of results for each informant and their arrangement into sixteen-year cohorts covering the period 1425-1503 allowed us to notice how the different members of the family, generation after generation, gradually adopted the new form $<$ th $>$ and left the old $<\mathrm{p}\rangle$ behind in the course of the fifteenth century. It was also detected that the transition from the categorical use of the conservative form to the categorical use of the innovative one took place through a stage of variability where both variants co-existed, with letters in which both formas alternated, as in the following draft letter by John Paston III (perhaps to Thomas Playter, 1461 March): "my fadyr is in a dowte whedir he shall send my broper vp or not, for he wold have his owne men abowte hym [...] [M]y brother is redyn to Yarmowth for to lette brybours that wold a robbed ship vndyr colour of my lord of Warwyk, [...]" (Davis 19711976: letter 317, page 520; emphasis added). 
In that study, it was also shown that the most advanced users of the $<$ th $>$ innovation were members of the family with intense social and geographical mobility, who had the potential to establish weak ties with other speakers in loose-knit networks. This was the case of John Paston I (82\%) -an outstanding user of the new variant in the second generation, in contrast, for instance, to his brother Edmond Paston I (53\%)-as well as of John Paston III (89\%), from the third generation. Nevertheless, the chronological progress of the innovation also accounts for the high rates obtained by other contemporary members of the family with closer networks and stronger links, like Walter Paston (86\%) or William Paston III (87\%) (see Figure 4).

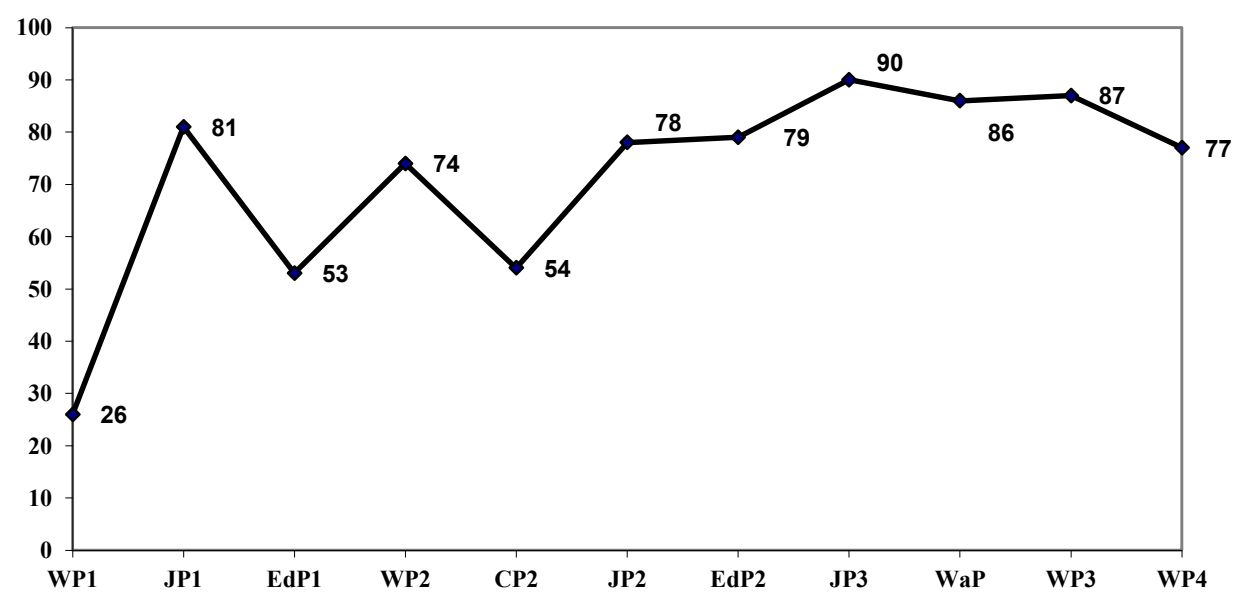

Figure 4. Average of the innovating $<$ th $>$ spelling in the correspondence of male members from the Paston family (Conde-Silvestre \& Hernández-Campoy 2013: 293; Figure 4)

With this study in mind, in this paper we are looking at this variable from a sociostylistic perspective trying to examine the role of style in this process of language change. The same data is used, but we focus only on the correspondence of some selected members of the Paston family with the aim of tracing the diffusion of this change from above in connnection with patterns of intra-speaker variation. Considering the indexical nature of variable (th), we believe that the interaction of some of our informants with socially different addressees and their respective personal profile may show the socio-stylistic route of adoption of the innovating variant $<$ th $>$. This is clearly attested in the letters by John Paston I, William Paston II, John Paston II and John Paston III, who interacted with members from all social ranks, practicing, therefore, both upward and downward accommodation. The pattern is also clear when the correspondence by Edmond Paston II and William 
Paston III is analysed, despite the narrower scope of their interaction, which is limited to relatives and members of the legal profession. The data afforded by other members of the family, such as William Paston I, Edmond Paston I, Clement Paston II and William Paston IV, have been discarded because their interaction is restricted to equals (relatives and family members), which hinders access to intra- and interspeaker observations.

In the case of John Paston I, his positions as Justice of Peace in Norfolk (1447, 1456-1457 and 1460-1466), Knight of the Shire (1455), and Member of Parliament for Norfolk (1460-1462) must have favoured the establishment of loose-knit, multiplex social networks, as reflected in the amount and social array of addressees found in his private correspondence in the period 1440-1469. At the same time, he had a central position in the close-knit network of the family and established strong ties with its members (see Figures 1 and 2). Therefore, the recipients of his letters can be socially situated in higher, equal, and lower positions, respectively for members of the royalty and the nobility (higher), his own wife and some members of the minor gentry (equal) and professionals (lower). The results obtained from the analysis of the letters (see Figure 5) show an average of $83 \%$ in the use of the spelling innovation $<$ th $>$, but there are differences connected with the social position of the addressees: upward accommodation when addressing letters to higher recipients (royalty and nobility: $94 \%$ ), or to professionals (86\%), but downward accommodation with minor gentry interlocutors - his equals - $(75 \%)$. Statistical analysis based on Pearson's Chi-square test confirms that his sociolinguistic practice did not occur by chance, with a significant relationship at $p<0.01\left(\chi^{2}=174.5141\right.$; $\left.\mathrm{df}=2\right)$.

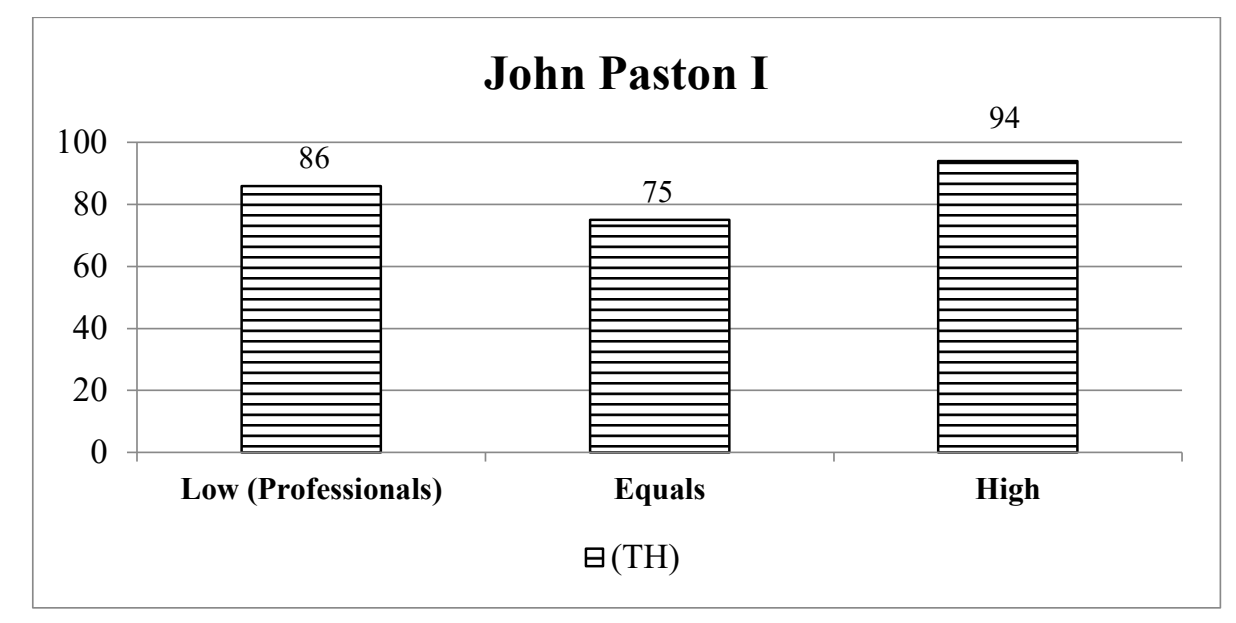

Figure 5. Percentages of the innovating $<$ th $>$ spelling in the letters by John Paston $\mathrm{I}$ in connection with his audience 
Despite generational differences, a similar patterning of $<\mathrm{th}>$ in connection with the social background of the addressees is observed in the letters by John I's son, John Paston III (1444-1504), who, as mentioned before, could also have established extensive personal relationships in multiplex, loose-knit networks, as reconstructed through his biography (see Figures 1 and 2). The rate of the protostandard variant $<$ th $>$ in his correspondence reaches $90 \%$, being consistently highly standard but with differing frequencies depending on the addresees of his private letters: the highest ratio (100\%) appears in texts sent to the nobility (with a higher social position) and the legal profession (with a lower status: 91\%), whereas the lowest scores occur in those addressed to his equals: mostly relatives and minor gentry (89\%) (see Figure 6). The Chi-square test confirms that his sociolinguistic behaviour did not operate arbitrarily, with a significant relationship at $p<0.01(\chi 2=22.327 ; \mathrm{df}=2)$.

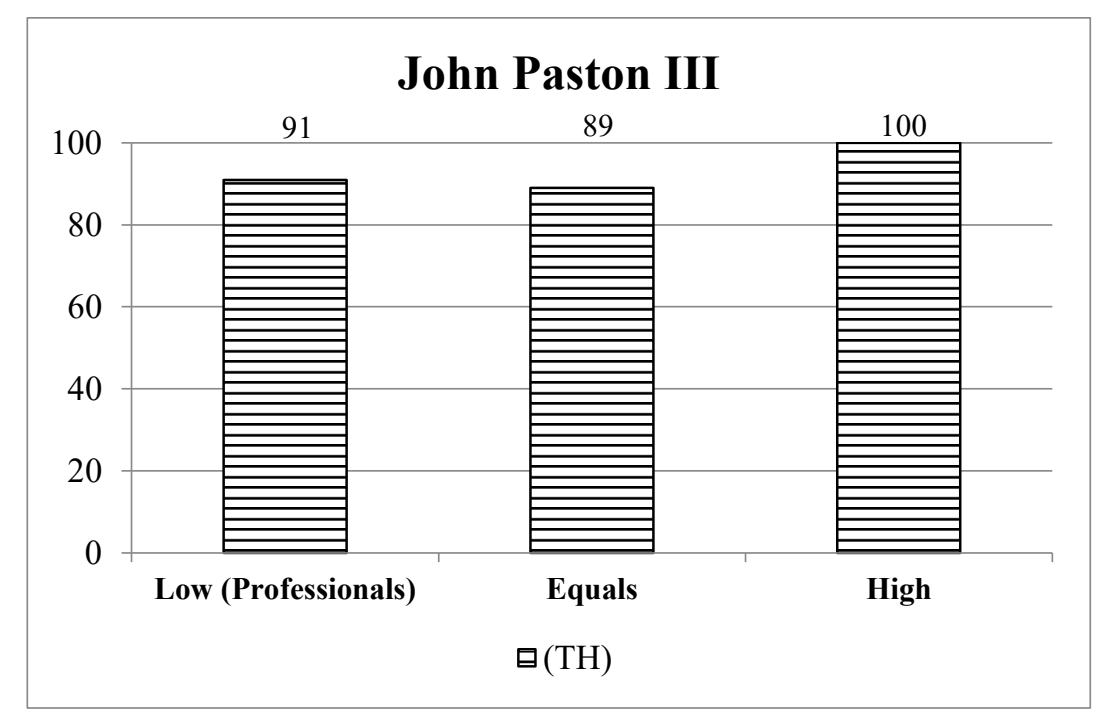

Figure 6. Percentages of the innovating $<$ th $>$ spelling in the letters by John Paston III in connection with his audience

Similarly, the diverse social networks established by William Paston II (14361496) make his sociolinguistic production also exhibit audience-based practices, as Figure 7 shows: $99 \%$ use of $<$ th $>$ forms with socially higher recipients, $69 \%$ with equals and $75 \%$ when addressing professionals. These rates are also statistically significant at $p<0.01(\chi 2=30.5632 ; \mathrm{df}=2) .{ }^{10}$

10 An exception to this conspicuous pattern occurs in the correspondence by John Paston II 


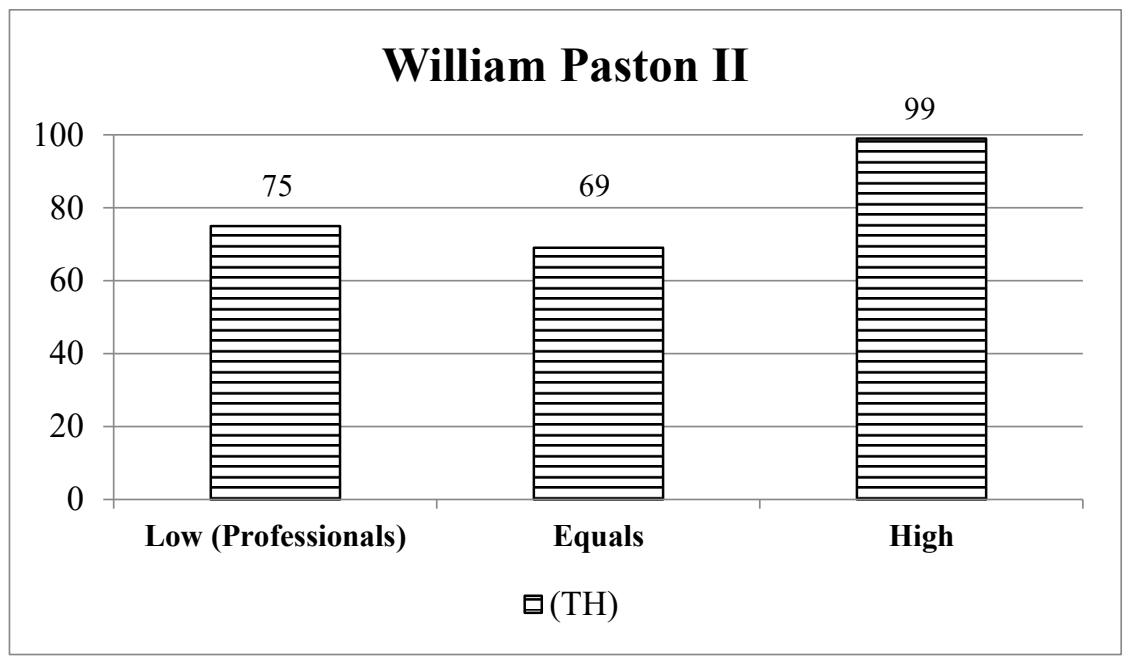

Figure 7. Percentages of the innovating $<$ th $>$ spelling in the letters by William Paston II in connection with his audience

Other members of the family did not have such an extensive audienceship as John Paston I, William Paston II, or John Paston III, probably because of their more limited social networks or because of the usually fragmentary availability of archival sources, an inherent problem in historical sociolinguistic research (see Hernández-Campoy \& Schilling 2012). However, the patterns of accommodative behaviour through style-shifting is also noticeable and affects the distribution of $<$ th $>$ in their letters. This is, for instance, the case of Edmond Paston II (1443?1504?) and of William Paston III (1459-1504?), in whose production the prestige of the language of law is clearly influential (see Figure 8). On average, both brothers show high rates in the use of the innovative spelling $<$ th $>, 79 \%$ and $87 \%$ respectively; however, their scores differ when they are seen in connection with the rank of their addressees, with $100 \%$ in the letters that both sent to members of the legal profession, despite their lower status - and $64 \%$ or $87 \%$ respectively in their correspondence with equals (members of their own family). Statistically, these quantitative patterns are significant in Edmond II's case $(p<0.01$; $\chi 2=88.521 ; \mathrm{df}=1)$ but not in William III's $(p>0.05 ; \chi 2=2.224 ; \mathrm{df}=1)$.

(1442-1479) which shows a low average of the innovative variant in letters addressed to the Royalty (33\%). A likely explanation for this is offered by Hernández-Campoy \& GarcíaVidal (2018a). 


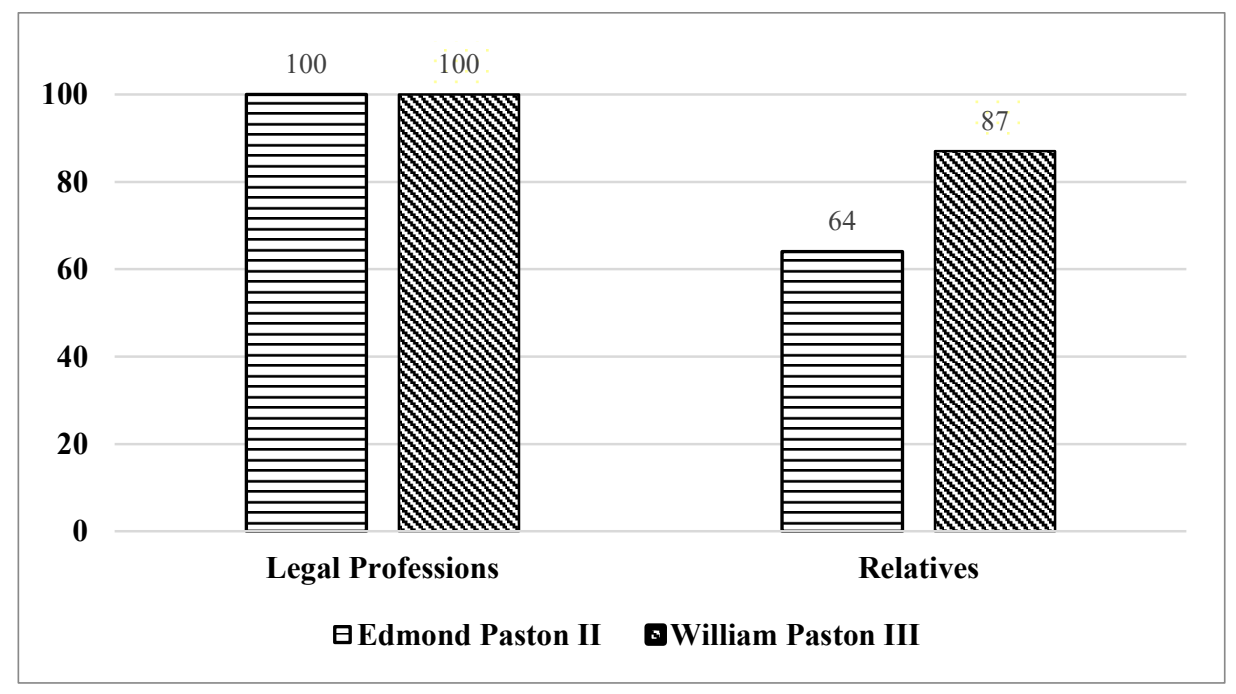

Figure 8. Percentages of the innovating $<$ th $>$ spelling in the letters by Edmond Paston II and William Paston III in connection to their audience

Interestingly, in their aggregate behaviour (see Figure 9), the same U-pattern of audience-based language production is obtained, with the socially higher group (royalty and nobility) and the lower one (legal professionals) encouraging the most frequent use of the innovative <th> variant: $89 \%$ with higher status addressees, $80 \%$ with equals, and $87 \%$ when addressing professionals. Inferential statistics based on Pearson's Chi-square test confirm that the aggregate sociolinguistic practices of these members from the Paston family did not occur by chance: the relationship is significant at $p<0.01(\chi 2=152.3099$; $\mathrm{df}=2)$. These patterned results would confirm that the diffusion of $<$ th $>$ is a change from above, which entered both the incipient standard English variety and the local community through imitation of prestige social groups. In this sense, the socially high users of the language (royalty, nobility, and clergy) obviously inspired upward accommodation, because they were the most overtly respected group. However, members from the lower rank (mainly legal professionals) also inspired upward accommodation, which can be related, in this case, to the technicality of their register and its association with the State offices, where from the 1430s the official language of law and administration was being coined (see Samuels 1963; Rissanen 1999, 2000). Additionally, these results confirm the conclusions reached in Hernández-Campoy and Conde-Silvestre (1999), in that the implementation of the more standard-like innovations progressed from formal to informal styles over time, involving a greater degree of proto-standardisation through the increasing appearance of the new variants in informal texts. 


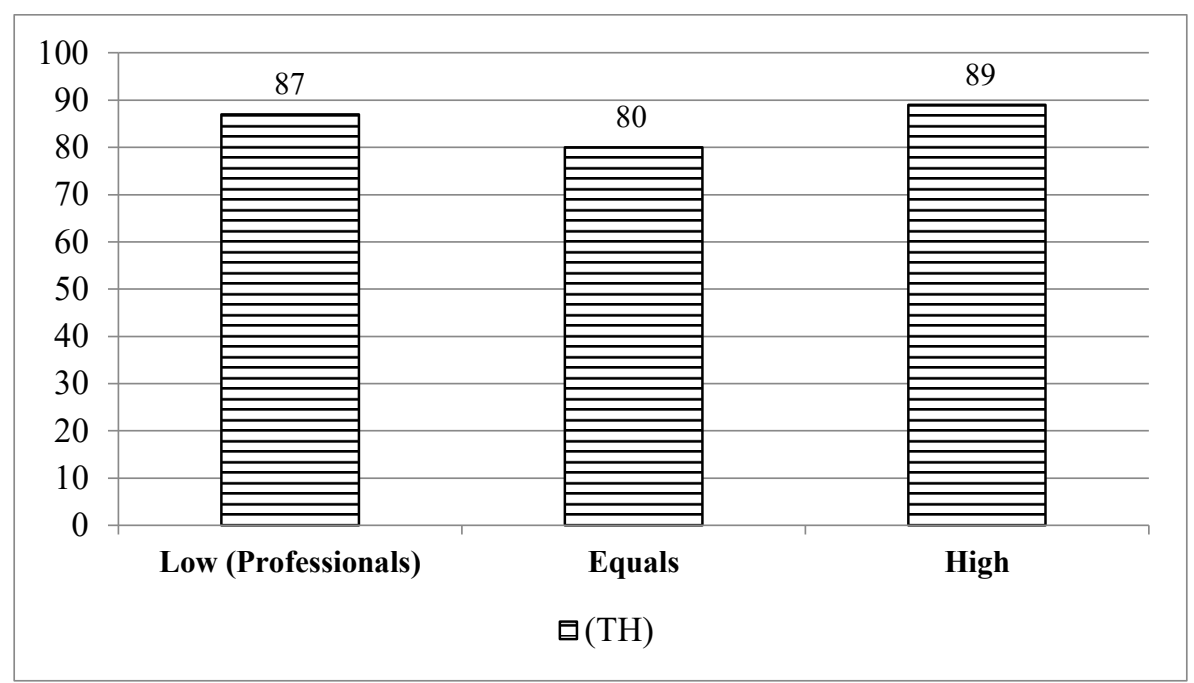

Figure 9. Global percentages of the innovating $<$ th $>$ spelling in the letters by John I, William II, John II, Edmond II, John III, and William III in connection with audience

\section{Conclusion}

From the above discussion, several conclusions can be reached. The sociostylistic route followed by the innovative $<$ th $>$ spelling in the fifteenth century has been traced through socially high prestigious groups and in the stylistically more formal contexts. This clear connection of the use of $<\mathrm{th}>$ with formality and with the rank of the addressees confirms the status of the innovation as a change from above, both in the sense of diffusing from above the level of consciousness - from formal to informal contexts and text-types - and from the upper social layers, as previously reported by Stenroos (2004, 2006) and Jensen (2012). Similarly, the linguistic features involved in stylistic variation are mostly the same as those marking social variation: i.e., those features typically found at the high end of the social scale are equally high on the stylistic scale, and vice versa. This is also the expected case in changes from above. Sociolinguistically, the special behaviour of variable (th) in this period may be due to its status of marker (subject to both social and stylistic variation), denoting some specific prestige patterns within the speech community of the period and also exhibiting a specific indexical meaning. Although the replacement of the $<\mathrm{p}>$ had already started in the Anglo-Saxon period, the progressive adoption of the digraph $<$ th $>$ from the Roman alphabet was completed under the influence of Latin on Anglo-Norman scribes during the Middle English period. As reported by Benskin (1982), the presence of the 
digraph $<$ th $>$ in both Latin and Biblical texts acted as an external prestigious norm that triggered the actuation of this orthographic change, so that the Roman-based form became overtly popular during the fourteenth and fifteenth centuries as a historical change operating above the level of social awareness. In late Middle English, the influence of professionals trained in the language of law and administration cannot be discarded. This process inevitably took place in connection with social and stylistic factors and diffused along the social space in the careful and conscious styles, thus acquiring overt prestige and becoming part of the accepted linguistic norm, as typical Labovian changes from above behave.

\section{REFERENCES}

Alexandropoulos, Georgios. 2015. Stylistic devices of Christians expressing contradiction against the Gentiles. In Cinzia Russi (ed.), Current trends in historical sociolinguistics, 19-45. Berlin: De Gruyter. DOI: 10.1515/9783110488401-005

Auer, Anita. 2015. Stylistic variation. In Anita Auer, Daniel Schreier \& Richard J. Watts (eds), Letter writing and language change, 133-155. Cambridge: Cambridge University Press. DOI: 10.1017/CBO9781139088275.009

Auer, Anita, Catharina Peersman, Simon Pickl, Gijsbert Rutten \& Rik Vosters. 2015. Historical sociolinguistics: The field and its future. Journal of Historical Sociolinguistics 1(1). 112. DOI: $10.1515 /$ jhsl-2015-0001

Barber, Richard. 1986. The Pastons. A family in the Wars of the Roses. Woodbridge: The Boydell Press.

Bell, Allan. 1984. Language style as audience design. Language in Society 13(2). 145-204.

Bell, Allan. 2001. Back in style: Reworking Audience Design. In Penelope Eckert \& John Rickford (eds), Style and sociolinguistic variation, 139-169. Cambridge: Cambridge University Press. DOI: 10.1017/CBO9780511613258.010

Bennett, Henry S. 1995 [1932]. The Pastons and their England: Studies in an age of transition (2nd edn). Cambridge: Cambridge University Press.

Benskin, Michael. 1977. Local archives and Middle English dialects. Journal of the Society of Archivists 5(8). 500-514. DOI: 10.1080/00379817709514090

Benskin, Michael. 1982. The letters $<\mathrm{p}>$ and $<\mathrm{y}>$ in later Middle English, and some related matters. Journal of the Society of Archivists 7(1). 13-30. DOI: 10.1080/00379818209514199

Bergs, Alexander. 2005. Social networks and historical sociolinguistics: Studies in morphosyntactic variation in the Paston Letters (1421-1503). Berlin: Mouton de Gruyter.

Biber, Douglas. 1995. Dimensions of register reconstruction. A cross-linguistic comparison. Cambridge: Cambridge University Press.

Biber, Douglas. 2001. Dimensions of variation among $18^{\text {th }}$ - century registers. In Hans-Jürgen Diller \& Manfred Görlach (eds), Towards a history of English as a history of genres, 89-110. Heidelberg: Carl Winter. 


\section{J. Hernández-Campoy, J. C. Conde-Silvestre and T. García-Vidal}

Biber, Douglas \& Edward Finegan. 1989. Styles of stance in English: Lexical and grammatical marking of evidentiality and affect. Text \& Talk 9(1). 93-124. DOI: 10.1515/text.1.1989.9.1.93

Biber, Douglas \& Edward Finegan. 1997. Diachronic relations among speech-based and written registers in English. In Terttu Nevalainen \& Leena Kahlas-Tarkka (eds), To explain the present: Studies in the changing English language in honour of Matti Rissanen, 253275. Helsinki: Société Neophilologique.

Blake, Norman F. 1992. Introduction. In Norman F. Blake (ed.), The Cambridge history of the English language. Vol. 2: 1066-1476, 1-22. Cambridge: Cambridge University Press.

Blume, Richard 1882. Die Sprache der Paston Letters. Beitrag zur historischen Grammatik des Englischen. Programm der Realschhule beim Doventhor zu Bremen.

Castor, Helen. 2004. Blood and roses. The Paston family in the fifteenth century. London: Faber \& Faber.

Christy, T. Craig. 1983. Uniformitarianism in linguistics. Amsterdam \& Philadelphia, PA: John Benjamins.

Conde-Silvestre, J. Camilo. 2007. Sociolingüistica histórica. Madrid: Gredos.

Conde-Silvestre, J. Camilo. 2012. The role of social networks and mobility in diachronic sociolinguistics. In Juan M. Hernández-Campoy \& J. Camilo Conde-Silvestre (eds), The handbook of historical sociolinguistics, 332-352. Malden, MA: Wiley-Blackwell. DOI: 10.1002/9781118257227.ch18

Conde-Silvestre, J. Camilo. 2016a. Historical sociolinguistics. In Jan-Ola Östman \& Jef Verschueren (eds), Handbook of pragmatics: 2016 installment. Amsterdam \& Philadelphia, PA: John Benjamins. DOI: 10.1075/hop.20.his4

Conde-Silvestre, J. Camilo. 2016b. A 'third-wave' historical sociolinguistic approach to late Middle English correspondence: Evidence from the Stonor Letters. In Cinzia Russi (ed.), Current Trends in Historical Sociolinguistics, 46-66. Berlin: De Gruyter. DOI: 10.1515/9783110488401-006

Conde-Silvestre, J. Camilo. 2019. Spelling focusing and proto-standardisation in a fifteenth-century English community of practice. Studia Neophilologica 91(1). 11-30. DOI: 10.1080/00393274.2019.1578181

Conde-Silvestre, J. Camilo \& Juan M. Hernández-Campoy. 2004. A sociolinguistic approach to the diffusion of Chancery written practices in late fifteenth century private correspondence. Neuphilologische Mitteilungen 105(2). 133-152.

Conde-Silvestre, J. Camilo \& Juan M. Hernández-Campoy. 2013. Tracing the generational progress of language change in fifteenth century English: The digraph $<$ th $>$ in the Paston Letters. Neuphilologische Mitteilungen 114(3). 279-299.

Coupland, Nikolas. 2007. Style: Language variation and identity. Cambridge: Cambridge University Press.

Davis, Norman O. 1989 [1954]. The language of the Pastons. In James A. Burrow (ed.), Middle English literature: British Academy Gollancz lectures, 45-70. Oxford: Oxford University Press.

Davis, Norman O. (ed.), 1971-1976. Paston letters and papers of the fifteenth century (2 vols). Oxford: Clarendon.

Davis, Norman O. 1983 The language of two brothers in the fifteenth century. In Eric G. Stanley \& Douglas Gray (eds), Five hundred years of words and sounds. A festschrift for Eric Dobson, 23-28. Cambridge: D.S. Brewer. 
Dressler, Wolfgang U. \& Ruth Wodak. 1982. Sociophonological methods in the study of sociolinguistic variation in Viennese German. Language in Society 11(3). 339-370.

Elspaß, Stephan. 2002. Standard German in the 19th-century? (Counter-) evidence from the private correspondence of "ordinary people". In Andrew R. Linn \& Nicola McLelland (eds), Standardization: Studies from the Germanic languages, 43-65. Amsterdam \& Philadelphia, PA: John Benjamins. DOI: 10.1075/cilt.235.05els

Gies, Frances \& Joseph Gies. 1998. A medieval family: The Pastons of fifteenth-century England. New York, NY: Harper Collins.

Gómez-Soliño, José. 1997. Pastons, Celys and the standard language in the late fifteenth century. In Margarita Giménez Bon \& Vicky Olsen (eds), Proceedings of the IXth international conference of the Spanish Society for Medieval English Language and Literature, 117139. Vitoria-Gasteiz: Universidad del País Vasco.

González Escribano, José Luis G. 1982. Word-order and stylistic distortion in the letters of William Paston I, 1425-1442: A transformational approach. Anglo American Studies 2. 85-112.

González Escribano, José Luis. 1985. Retórica epistolar en la Inglaterra del siglo XV: El caso de William Paston I, 1378-1444. In Fernando Galván (ed.), Estudios literarios ingleses. Edad Media, 253-283. Madrid: Cátedra.

Hernández-Campoy, Juan M. 2008. Overt and covert prestige in Late Middle English: A case study in East Anglia. Folia Linguistica Historica 29. 1-26. DOI: 10.1515/FLIH.2008.1

Hernández-Campoy, Juan M. 2016a. Sociolinguistic styles. Malden, MA: Wiley-Blackwell.

Hernández-Campoy, Juan M. 2016b. Authorship and gender in English historical sociolinguistic research: Samples from the Paston Letters. In Cinzia Russi (ed.), Current trends in historical sociolinguistics, 108-142. Berlin: De Gruyter. DOI: 10.1515/9783110488401-009

Hernández-Campoy, Juan M. \& J. Camilo Conde-Silvestre. 1999. The social diffusion of linguistic innovations in fifteenth century England: Chancery spellings in private correspondence. Cuadernos de Filología Inglesa 8. 251-274.

Hernández-Campoy, Juan M. \& J. Camilo Conde-Silvestre (eds). 2012. The handbook of historical sociolinguistics. Malden, MA: Wiley-Blackwell.

Hernández-Campoy, Juan M. \& J. Camilo Conde-Silvestre. 2015. Assessing variability and change in early English letters. In Anita Auer, Daniel Schreier \& Richard J. Watts (eds), Letter writing and language change, 14-34. Cambridge: Cambridge University Press. DOI: 10.1017/CBO9781139088275.003

Hernández-Campoy, Juan M. \& Tamara García-Vidal. 2018a. Persona management and identity projection in English medieval society: Evidence from John Paston II. Journal of Historical Sociolinguistics 4(1). 1-31. DOI: 10.1515/jhsl-2016-0027

Hernández-Campoy, Juan M. \& Tamara García-Vidal. 2018b. Style-shifting and accommodative competence in Late Middle English written correspondence: Putting audience design to the test of time. Folia Linguistica Historica 39(2). 383-420. DOI: 10.1515/flih-2018-0014

Hernández-Campoy, Juan M. \& Natalie Schilling-Estes. 2012. The application of the quantitative paradigm to historical sociolinguistics: Problems with the generalizability principle. In Juan M. Hernández-Campoy \& J. Camilo Conde-Silvestre (eds), The handbook of historical sociolinguistics, 63-79. Malden, MA: Wiley-Blackwell. DOI: 10.1002/9781118257227.ch4

Hickey, Raymond. 1999. Developments and change in Dublin English. In Ernst Håkon Jahr (ed.), Language change. Advances in historical sociolinguistics, 209-243. Berlin: Mouton de Gruyter. 


\section{J. Hernández-Campoy, J. C. Conde-Silvestre and T. García-Vidal}

Hogg, Richard. 1992. Phonology and morphology. In Richard Hogg (ed.), The Cambridge history of the English language. Vol 1: The beginnings to 1066, 67-167. Cambridge: Cambridge University Press. DOI: 10.1017/CHOL9780521264747.004

Jensen, Vibeke. 2012. The consonantal element (th) in some late Middle English Yorkshire texts. In Jukka Tyrkkö, Matti Kilpiö, Terttu Nevalainen \& Matti Rissanen (eds), Outposts of historical corpus linguistics: From the Helsinki Corpus to a proliferation of resources. Helsinki: Research Unit for Variation, Contact and Change in English. https://www.helsinki.fi/varieng/series/volumes/10/jensen/ [Accessed April 20, 2019].

Labov, William. 1966a. The social stratification of English in New York City. Washington, DC: Center for Applied Linguistics.

Labov, William. 1966b. Hypercorrection by the lower middle class as a factor in linguistic change. In William Bright (ed.), Sociolinguistics: Proceedings of the UCLA Sociolinguistics Conference, 1964, 84-113. The Hague: Mouton. DOI: 10.1515/9783110856507-008

Labov, William. 1972. Sociolinguistic patterns. Philadelphia, PA: University of Pennsylvania Press.

Labov, William. 1973. The linguistic consequences of being a lame. Language in Society 2(1). 81115. DOI: $10.1017 / \mathrm{S} 0047404500000075$

Labov, William. 1994. Principles of linguistic change. Vol. 1: Internal factors. Oxford: Blackwell.

Labov, William. 2001. The anatomy of style-shifting. In Penelope Eckert \& John R. Rickford (eds) Style and sociolinguistic variation, 85-108. Cambridge: Cambridge University Press. DOI: $10.1017 / \mathrm{CBO} 9780511613258.006$

Lass, Roger. 1992. Phonology and morphology. In Norman F. Blake (ed.), The Cambridge history of the English language. Vol 2: 1066-1476, 23-155. Cambridge: Cambridge University Press. DOI: 10.1017/CHOL9780521264754.003

Maas, Utz. 1988 On the interpretive analysis of historical records: Linguistic relations in seventeenth century Osnabrück. In Peter Auer \& Aldo di Luzio (eds), Variation and convergence, 11-43. Berlin: Walter de Gruyter.

Mattheier, Klaus. 1981. Wege und Umwege zur neuhochdeutschen Schriftsprache. Zeitschrift für Germanistische Linguistik 9(3). 274-307. DOI: 10.1515/zfgl.1981.9.3.274

McIntosh, Angus. 1974. Towards an inventory of Middle English scribes. Neuphilologische Mitteilungen 75(4). 602-624.

Meyerhoff, Miriam. 2006. Introducing sociolinguistics. London: Routledge.

Millar, Robert McColl. 2012. English historical sociolinguistics. Edinburgh: Edinburgh University Press.

Milroy, James \& Lesley Milroy 1985. Linguistic change, social network and speaker innovation. Journal of Linguistics 21(2). 339-384. DOI: 10.1017/S0022226700010306

Milroy, Lesley. 1987. Language and social networks (2nd edn). Oxford: Blackwell.

Milroy, Lesley. 2002. Social networks. In Jack K. Chambers, Peter Trudgill \& Natalie SchillingEstes (eds), The handbook of language variation and change, 549-572. Oxford \& Malden, MA: Blackwell.

Mihm, Arend, Michael Elmentaler, Stephanie Heth, Kerstin Salewski \& Tim Stichlmair. 2000. Die frühneuzeitliche Überschichtung der rheinmaasländischen Stadtsprachen. Ein Duisburger Forschungsprojekt zur Entstehung der deutsch-niederländischen Sprachgrenze. In Michael Elmentaler (ed.), Regionalsprachen, Stadtsprachen und Institutionssprachen im historischen Prozess, 117-156. Vienna: Edition Praesens.

Nevala, Minna \& Minna Palander-Collin. 2005. Letters and letter writing: Introduction. European Journal of English Studies 9(1). 1-7. DOI: 10.1080/13825570500067903 
Nevalainen, Terttu. 2006. Historical sociolinguistics and language change. In Ans van Kemenade \& Bettelou Los (eds), The handbook of the history of English, 558-588. Malden, MA: Wiley Blackwell. DOI: 10.1002/9780470757048.ch22

Nevalainen, Terttu 2007. Introduction. In Terttu Nevalainen \& Sanna Kaisa Tanskanen (eds), Letter writing, 1-11. Amsterdam \& Philadelphia, PA: John Benjamins. DOI: $10.1075 /$ bct.1.02nev

Nevalainen, Terttu. 2011. Historical sociolinguistics. In Ruth Wodak, Barbara Johnstone \& Paul Kerswill (eds), The Sage handbook of sociolinguistics, 279-295. London: Sage.

Nevalainen, Terttu. 2015. What are historical sociolinguistics? Journal of Historical Sociolinguistics 1(2). 243-269. DOI: 10.1515/jhsl-2015-0014

Nevalainen, Terttu \& Helena Raumolin-Brunberg (eds). 1996. Sociolinguistics and language history: Studies based on the Corpus of Early English Correspondence. Amsterdam: Rodopi.

Nevalainen, Terttu \& Helena Raumolin-Brunberg. 2012. Historical sociolinguistics: Origins, motivations, and paradigms. In Juan M. Hernández-Campoy \& J. Camilo CondeSilvestre (eds), The handbook of historical sociolinguistics, 22-40. Malden, MA: Wiley-Blackwell. DOI: 10.1002/9781118257227.ch2

Nevalainen, Terttu \& Helena Raumolin-Brunberg. 2017. Historical sociolinguistics. Language change in Tudor and Stuart England (2nd edn). London: Routledge. DOI: 10.4324/9781315475172

Palander-Collin, Minna. 2010. Correspondence. In Andreas H. Jucker \& Irma Taavitsainen (eds), The handbook of historical pragmatics, 651-678. Berlin \& New York, NY: Mouton de Gruyter. DOI: 10.1515/9783110214284.7.651

Palander-Collin, Minna, Minna Nevala \& Arja Nurmi. 2009. The language of daily life in the history of English. Studying how macro meets micro. In Arja Nurmi, Minna Nevala \& Minna Palander-Collin (eds), The language of daily life in England (1400-1800), 123. Amsterdam \& Philadelphia, PA: John Benjamins. DOI: 10.1075/pbns.183.02pal

Raumolin-Brunberg, Helena. 1996. Historical sociolinguistics. In Terttu Nevalainen \& Helena Raumolin-Brunberg (eds), Sociolinguistics and language history: Studies based on the Corpus of Early English Correspondence, 11-37. Amsterdam: Rodopi.

Reid, Euan. 1978. Social and stylistic variation in the speech of children: Some evidence from Edinburgh. In Peter Trudgill (ed.), Sociolinguistic patterns in British English, 158-171. London: Edward Arnold.

Richmond, Colin. 1996. The Paston family in the fifteenth century. Vol. 2: Fastolf's will. Cambridge: Cambridge University Press.

Richmond, Colin. 2000. The Paston family in the fifteenth century. Vol. 3: Endings. Manchester: Manchester University Press.

Richmond, Colin. 2002. The Paston family in the fifteenth century. Vol. 1: The first phase (2nd edn). Cambridge: Cambridge University Press.

Richmond, Colin. 2004. Paston family (per. c. 1420-1504). Oxford dictionary of national biography. Oxford: Oxford University Press. https://www.oxforddnb.com/view/article/52791 [Accessed March 27, 2019].

Rickford, John \& Penelope Eckert. 2001. Introduction. In Penelope Eckert \& John Rickford (eds) Style and sociolinguistic variation, 1-18. Cambridge: Cambridge University Press. DOI: $10.1017 / \mathrm{CBO} 9780511613258.001$

Rissanen, Matti. 1999. The language of law and the development of standard English. In Irma Taavitsainen, Gunnel Melchers \& Päivi Pahta (eds), Writing in non-standard English, 189-204. Amsterdam \& Philadelphia, PA: John Benjamins. 


\section{J. Hernández-Campoy, J. C. Conde-Silvestre and T. García-Vidal}

Rissanen, Matti. 2000. Standardisation and the language of early statutes. In Laura Wright (ed.), The development of standard English 1300-1800: Theories, descriptions, conflicts, 117-130. Cambridge: Cambridge University Press. DOI: 10.1017/CBO9780511551758.008

Romaine, Suzanne. 1978. Postvocalic/r/ in Scottish English: Sound change in progress? In Peter Trudgill (ed.), Sociolinguistic patterns in British English, 144-157. London: Edward Arnold.

Romaine, Suzanne. 1982. Socio-historical linguistics. Its status and methodology. Cambridge: Cambridge University Press.

Romaine, Suzanne. 1998. Introduction. In Suzanne Romaine (ed.), The Cambridge history of the English language. Vol. 2: 1776-1997, 1-56. Cambridge: Cambridge University Press. DOI: $10.1017 /$ CHOL9780521264778.002

Sairio, Anni. 2009. Language and letters of the Bluestocking network: Sociolinguistic issues in eighteenth-century epistolary English. Helsinki: Société Néophilologique.

Samuels, Michael Louis. 1963. Some applications of Middle English dialectology. English Studies 44. 81-94. DOI: 10.1080/00138386308597155

Schäfer, Ursula. 1996. The late Middle English Paston letters: A grammatical case in point for reconsidering philological methodologies. In Jürgen Klein \& Dirk Vanderbeke (eds), Anglistentag 1995 Greifswald, 313-323. Tübingen: Niemeyer.

Schiegg, Markus. 2016. Code-switching in lower-class writing: Autobiographies by patients from southern German psychiatric hospitals (1852-1931). Journal of Historical Sociolinguistics 2(1). 47-81. DOI: 10.1515/jhsl-2016-0003

Schneider, Edgar W. 2002. Investigating variation and change in written documents. In Jack K. Chambers, Peter J. Trudgill \& Natalie Schilling-Estes (eds), The handbook of language variation and change, 67-96. Oxford: Blackwell. DOI: 10.1002/9780470756591.ch3

Scragg, Donald G. 1974. A history of English spelling. Manchester: Manchester University Press.

Stenroos, Merja. 2004. Regional dialects and spelling conventions in late Middle English. Searches for (th) in the LALME data. In Marina Dossena \& Roger Lass (eds), Methods and data in English historical dialectology, 257-285. Bern: Peter Lang.

Stenroos, Merja. 2006. A Middle English mess of fricative spellings: Reflections on thorn, yogh and their rivals. In Marcin Krygier \& Liliana Sikorska (eds), To make his Englissh sweete upon his tonge, 9-36. Frankfurt a. Main: Peter Lang.

Taavitsainen, Irma. 2000. Scientific language and spelling standardisation 1375-1550. In Laura Wright (ed.), The development of standard English 1300-1800: Theories, descriptions, conflicts, 131-154. Cambridge: Cambridge University Press.

Tanabe, Harumi. 1999. Composite predicates and phrasal verbs in the Paston Letters. In Laurel J. Brinton \& Minoji Akimoto (eds), Collocational and idiomatic aspects of composite predicates in the history of English, 97-132. Amsterdam \& Philadelphia, PA: John Benjamins.

Tieken-Boon van Ostade, Ingrid. 2005. Of social networks and linguistic influence: The language of Robert Lowth and his correspondents. International Journal of English Studies 5(1). $135-157$.

Tieken-Boon van Ostade, Ingrid. 2006. Eighteenth-century English letters: In search of the vernacular. Linguistica e Filologia 21. 113-146.

Trudgill, Peter. 1974. The social differentiation of English in Norwich. Cambridge: Cambridge University Press. 
Ure, Jean. 1982. Introduction: Approaches to the study of register range. International Journal of the Sociology of Language 35. 5-24. DOI: 10.1515/ijsl.1982.35.5

Voeste, Anja. 2018. The self as a source. A peasant farmer's letters from prison (1848-1852). Journal of Historical Sociolinguistics 4(1). 97-118. DOI: 10.1515/jhsl-2017-0011

Voitl, Herbert 1988. The history of voicing of initial fricatives in Southern England: A case of conflict between regional and social dialect. In Jacek Fisiak (ed.), Historical dialectology: Regional and social, 565-600. Berlin: Mouton de Gruyter. DOI: $10.1515 / 9783110848137.565$

Wood, Johanna L. 2007. Text in context: A critical discourse analysis approach to Margaret Paston. In Terttu Nevalainen \& Sanna Kaisa Tanskanen (eds), Letter writing, 47-71. Amsterdam \& Philadelphia, PA: John Benjamins. DOI: 10.1075/bct.1.05woo 


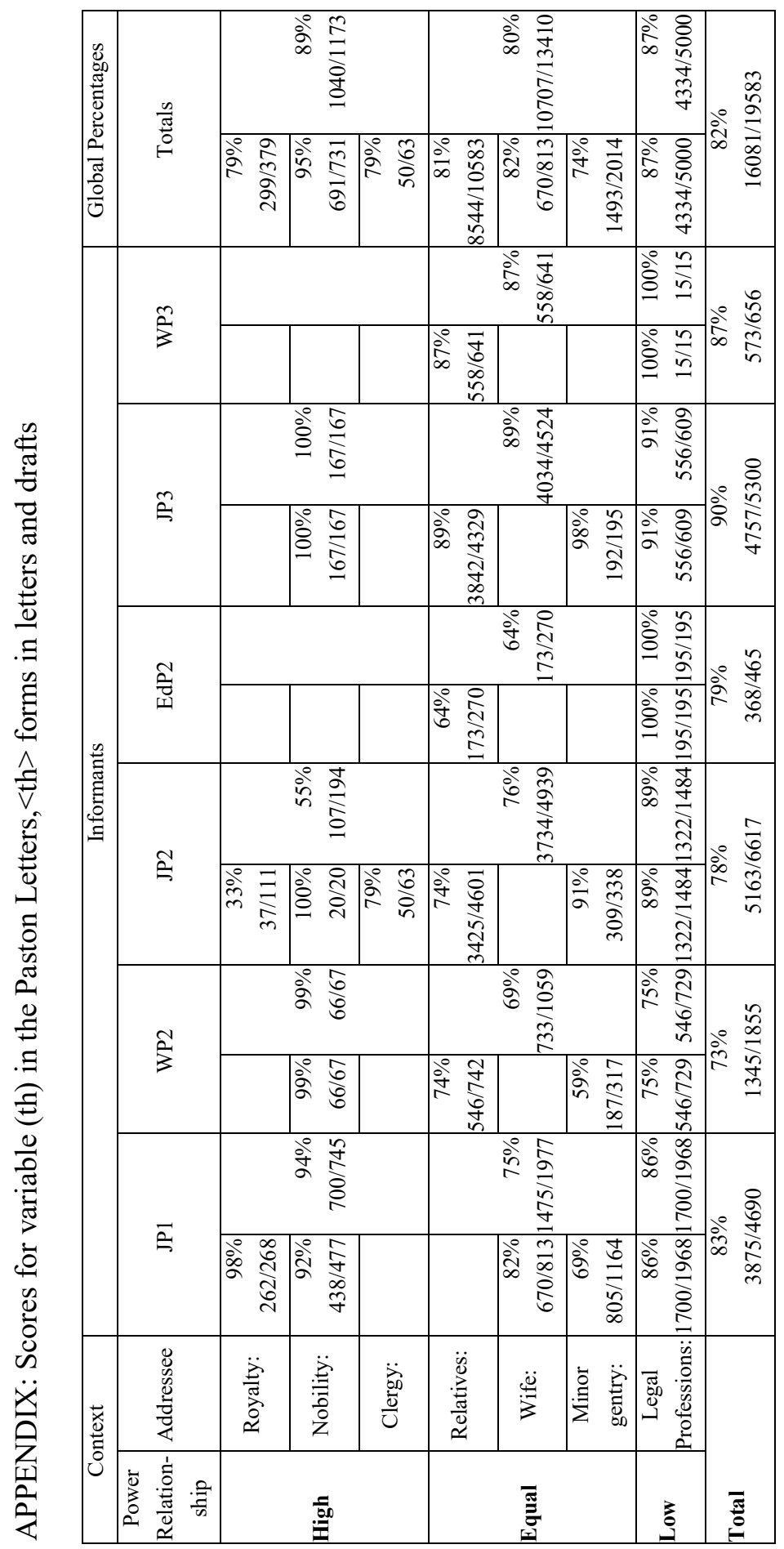

